\title{
Seroprevalence of anti-Leishmania spp. antibodies in rural dogs from the city of Monte Negro, State of Rondônia, Brazil
}

\author{
Soroprevalência de anticorpos anti-Leishmania spp. em cães rurais \\ do município de Monte Negro, Estado de Rondônia, Brasil \\ Daniel M. Aguiar1*; Trícia Maria F. de Sousa Oliveira²; Guacyara T. Cavalcante³; Marcelo B. Labruna³; \\ Luis Marcelo A. Camargo ${ }^{4}$; Rosangela Z. Machado²; Solange M. Gennari ${ }^{3}$
}

\begin{abstract}
${ }^{1}$ Departamento de Clínica Médica Veterinária, Faculdade de Agronomia e Medicina Veterinária, Universidade Federal de Mato Grosso - UFMT

${ }^{2}$ Departamento de Patologia Veterinária, Faculdade de Ciências Agrárias e Veterinárias, Universidade Estadual Paulista - UNESP

${ }^{3}$ Departamento de Medicina Veterinária Preventiva e Saúde Animal, Faculdade de Medicina Veterinária e Zootecnia, Universidade de São Paulo - USP

${ }^{4}$ Instituto de Ciências Biomédicas V, Universidade de São Paulo - USP
\end{abstract}

Received June 6, 2009

Accepted August 7, 2009

\begin{abstract}
The present study assessed the prevalence of anti-Leishmania spp. antibodies in dogs from the city of Monte Negro, State of Rondônia, Brazil. ELISA (NE $\geq 3$ ) and IFAT ( $\geq 1: 40)$ were used to evaluate 161 serum samples collected from rural dogs from Monte Negro. Forty-five (27.9\%) dogs were positive by ELISA tests and five (3.1\%) were positive by IFAT. The present study showed for the first time the frequency of exposure to Leishmania spp. in dogs in the State of Rondônia, Amazon Region.
\end{abstract}

Keywords: Leishmania spp., prevalence, dogs, ELISA, IFAT.

\section{Resumo}

O presente estudo determinou a prevalência de anticorpos anti-Leishmania spp. em cães do município de Monte Negro, Estado de Rondônia, Brasil. Foram utilizados os testes de ELISA (NE $\geq 3$ ) e RIFI ( $\geq 1: 40)$ para avaliar 161 amostras de soro de cáes da zona rural do município. Quarenta e cinco cáes $(27,9 \%)$ reagiram no teste de ELISA e cinco $(3,1 \%)$ na RIFI. O presente estudo demonstra pela primeira vez a freqüência de exposição por Leishmania spp. em cães de Rondônia, Região Amazônica.

Palavras-chave: Leishmania spp., prevalencia, cáes, ELISA, RIFI.

Leishmaniasis is a worldwide infection disease of humans and animals, caused by intra-mononuclear protozoans of the genus Leishmania, which are transmitted to susceptible hosts by phlebotomines of the genus Lutzomyia in Brazil (DANTAS-TORRES, 2008). Visceral leishmaniasis is one of the most important zoonotic diseases in South America, mainly in Brazil, where it is caused by Leishmania (Leishmania) chagasi (ARIAS, 1996). The presence of Leishmania spp. or antibodies against Leishmania spp. has been reported nationwide (DANTAS-TORRES, 2008), but some regions such as rural area of the city of Monte Negro, State of Rondônia, Northern Brazil, has no information about it.

\footnotetext{
*Corresponding author: Daniel M. Aguiar

Departamento de Clínica Médica Veterinária,

Faculdade de Agronomia e Medicina Veterinária,

Universidade Federal de Mato Grosso - UFMT

Av. Fernando Corrêa da Costa, s/n, CEP 78060-900 Cuiabá - MT, Brasil;

e-mail:danmoura@ufmt.br
}

In an effort to investigate the frequency of antibodies against Leishmania spp., serum samples from dogs collected in Rondônia were tested by indirect immunofluorescence antibody test (IFAT) and enzyme-linked immunosorbent assay (ELISA).

Dogs serum samples were obtained in the rural area of the city of Monte Negro, State of Rondônia, in the western Amazonian Region of Brazil (10 $10^{\circ} \mathrm{S}$ and $\left.63^{\circ} 14^{\prime} \mathrm{W}\right)$. These serum samples were collected during Aguiar et al. study (2006) who evaluated the prevalence of antibodies against Neospora caninum in cattle and dogs. The rural area of Monte Negro comprised 722 cattle farms and most of them had at least one dog. The number of sampled farms was determined with an estimated prevalence of $50 \%$, absolute desired precision of 10 and $95 \%$ confidence interval. Thus, 86 farms were randomly selected and all dogs found in these farms were sampled, totaling 161 dogs (range of one to six dogs per farm) from 70 farms.

All serum samples $(\mathrm{n}=161)$ were tested by IFAT and ELISA using $L$. chagasi antigen preparations and methods described by 
Oliveira et al. (2008). To calculate a measure of agreement between ELISA and IFAT, the results were assessed using the Cohn's Kappa coefficient with $95 \%$ confidence interval.

Of 161 rural dog samples tested, 45 (27.9\%) were positive against $L$. chagasi antigens by ELISA and only 5 (3.1\%) were positive by IFAT (titers between 40 and 1280). Among the 45 ELISA positive sera, only three $(6.6 \%)$ were positive by IFAT. The Kappa test showed a lower agreement of 0.248 (95\% CI: 0.171-0.325).

The positive sera $(27.9 \%)$ found in the ELISA compared to IFAT $(3.1 \%)$ are probably due to differences in the antigens used. ELISA methods using crude antigens of $L$. chagasi are considered less specific than IFAT, and can result in false-positive and negative reactions (SALOTRA et al., 2002). ELISA and IFAT methods using crude antigens are recommended by Brazilian Ministry of Health, but they show highly variable effectiveness to detect canine L. chagasi infection, mainly due to cross-reactivity of samples from dogs infected with other trypanosomatids such as L. braziliensis and Trypanosoma cruzi and low ability to detect seropositivity in asymptomatic dogs (PALATNIK-DE-SOUSA et al. 2001). The study region is also characterized by the endemic occurrence of other Leishmania species (SHAW et al., 2007) and Trypanosomatidae (Trypanosoma spp.) (UMEZAWA et al., 2009), which may have contributed to the difference observed between the two tests. According to the Brazilian Ministry of Health, in 2004, 2,131 cases of cutaneous leishmaniasis were reported in humans in Rondônia, confirming the importance of this infection in the western Amazonian region of Brazil (BRASIL, 2006). However, recent observations made by Gil et al. (2003) suggest there is a risk that visceral leishmaniasis could become an endemic disease in Rondônia because the presence of Lutzomyia longipalpis was identified in this region.

Many authors have reported differences between results obtained by ELISA and IFAT (BRAGA et al. 1998; METTLER et al., 2005). These differences are expected, and the use of both methods is interesting. ELISA allows simultaneous analysis of a large number of samples in a short time and IFAT can be used to confirm the specificity of positive samples, which is essential to an efficient diagnosis of canine visceral leishmaniasis. In conclusion, the results found in the present study are the first confirmation of the presence of antibodies against Leishmania spp. in dogs from Monte Negro, State of Rondônia.

\section{Acknowledgments}

To M. G. Spolidorio for language support and Conselho Nacional de Desenvolvimento Científico e Tecnológico (CNPQ) for the grants to M.B. Labruna, S.M. Gennari and R.Z. Machado.

\section{References}

AGUIAR, D. M. et al. Prevalence of anti-Neospora caninum antibodies in cattle and dogsfrom Western Amazon, Brazil, in association with some possible risk factors. Veterinary Parasitology, v. 142, n. 1-2, p. 71-77, 2006.

ARIAS, J. Epidemiología y control de la leishmaniasis en la Américas, por país o territorio. Washington: Organización Panamericana de la Salud, 1996. 52 p. (Cuaderno técnico, 44)

BRAGA, M. D. M. et al. Controle do calazar canino: comparação dos resultados de um programa de eliminação rápida de cães sororreagentes por ensaio imuno-enzimático com outro de eliminação tardia de cáes sororreagentes por teste de imunofluorescência indireta de eluato de papel de filtro. Revista Sociedade Brasileira de Medicina Tropical, v. 31 , n. 5 , p. $419-424,1998$

BRASIL. MINISTÉRIO DA SAÚDE. Sistema nacional de vigilância em saúde. Relatório de situação: Rondônia. 2 ed. Brasília, 2006. 24 p.

DANTAS-TORRES, F. Canine vector-borne diseases in Brazil. Parasites \& Vector, v. 1, n. 25, p. 1-17, 2008.

GIL, L. H. et al. Recent observations on the sand fly (Diptera: Psychodidae) fauna of the State of Rondônia, Western Amazônia, Brazil: the importance of Psychdopygus davisi as a vector of zoonotic cutaneous leishmaniasis. Memórias do Instituto Oswaldo Cruz, v. 98, n. 6, p. $751-755,2003$.

METTLER, M. et al. Evaluation of enzyme-linked immunosorbent assays, an immunofluorescent-antibody test, and two rapid tests (immunochromatographic-dipstick and gel tests) for serological diagnosis of symptomatic and asymptomatic Leishmania infections in dogs. Journal Clinical Microbiology, v. 43, n. 11, p. 5515-5519, 2005.

OLIVEIRA, T. M. F. S. et al. A study of cross-reactivity in serum samples from dogs positive for Leishmania sp, Babesia canis and Ehrlichia canis in enzyme-linked immunosorbent assay and indirect fluorescent antibody test. Revista Brasileira de Parasitologia Veterinária, v. 17, n. 1, p. 7-11, 2008.

PALATNIK-DE-SOUSA, C. B. et al. Impact of canine control on the epidemiology of canine and human visceral leishmaniasis in Brazil. American Journal of Tropical Medicine and Hygiene, v. 65, n. 5, p. 510-517, 2001.

SALOTRA, P. et al. Evaluation of enzyme-linked immunosorbent assay for diagnosis of post-kalazar dermal leishmaniasis with crude or recombinant k39 antigen. Clinical and Diagnostic Laboratory Immunology, v. 9, n. 2, p. 370-373, 2002.

SHAW, J. J. et al. The aetiological agents of American cutaneous leishmaniasis in the municipality of Monte Negro, Rondônia state, western Amazonia, Brazil. Annals of Tropical Medicine and Parasitology, v. 101, n. 8, p. 681-688, 2007.

UMEZAWA, E. S. et al. TESA-blot for the diagnosis of chagas disease in dogs from co-endemic regions for Trypanosoma cruzi, Trypanosoma evansi and Leishmania chagasi. Acta Tropica, v. 111, n. 1, p. 15-20, 2009. 